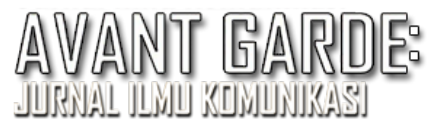

p-JSSN: $23338-4,30 \mathrm{~J}$

(5- $-155 N^{2}=235 \%-151 \%$

\title{
Strategi Hubungan Masyarakat Kementerian Koperasi dan Usaha Kecil dan Menengah Republik Indonesia Dalam Menyosialisasikan Program Kredit Usaha Rakyat Melalui Media Sosial
}

\author{
Wenny Maya Arlena \\ wenny.maya@budiluhur.ac.id \\ Universitas Budi Luhur, Jl. Ciledug Raya, Petukangan Utara, Jakarta Selatan, 12260
}

Submitted: 21 April 2020 Revised: 04 Mei 2020 Accepted: 20 Mei 2020

\begin{abstract}
Abstrak
Kementerian Koperasi dan Usaha Kecil dan Menengah Republik Indonesia adalah kementerian yang membidangi Koperasi dan kredit Usaha Rakyat. Kementerian Koperasi dan Usaha Kecil Menengah memiliki sembilan program unggulan yang salah satu diantaranya adalah program Kredit Usaha Rakyat (KUR). Program KUR ini bertujuan untuk Mempercepat pengembangan Sektor Riil dan Pemberdayaan Usaha Mikro, Kecil, Menengah, dan Koperasi (UMKMK), meningkatkan akses pembiayaan dan mengembangkan UMKM dan Koperasi kepada Lembaga Keuangan, sebagai upaya penanggulangan/pengentasan kemiskinan dan perluasan kesempatan kerja, khususnya bagi para Usaha Kecil Menengah. Tujuan penelitian ini adalah untuk mengetahui Strategi Humas Kementerian Koperasi dan Usaha Kecil dan Menengah RI dalam menyosialisasikan sembilan Program unggulannya, salah satunya adalah Kredit Usaha Rakyat (KUR) melalui media sosial yaitu facebook, twitter dan instagram, berisikan informasiinformasi yang dibutuhkan para UKM agar mendapatkan informasi terkini dari pemerintah pusat tentang perkembangan seputar UKM di Indonesia. Namun dari ketiga media sosial yang ada, facebook menjadi fokus utama dalam menyosialisasikan program KUR, karena facebook adalah media sosial yang memiliki banyak fitur. Teori yang digunakan adalah teori POAC (Planning, Organizing, Actuating, Controling) oleh George R. Terry. Paradigma menggunakan konstruktivisme dengan pendekatan deskriptif kualitatif, sedangkan metode penelitian menggunakan wawancara mendalam dan observasi partisipan untuk mendapatkan data primer. Hasil penelitian adanya temuan bahwa media sosial, tidak hanya sebagai wadah pengenalan hingga sosialisasi informasi saja, tetapi juga sebagai penyebaran secara luas melalui arus informasi
\end{abstract}

Kata Kunci $\quad$ : media sosial, public relations, sosialisasi, strategi,

\section{Strategy of Public Relations The Ministry of Koperasi dan Usaha Kecil dan Menengah of The Republic of Indonesia in Socializing Kredit Usaha Rakyat Programs Through Social Media}

\begin{abstract}
Abstrack
The Ministry of Koperasi dan Usaha Kecil dan Menengah of the Republic of Indonesia is the ministry in charge of Koperasi dan Kredit Usaha Rakyat. The Ministry of Koperasi dan Usaha Kecil dan Menengah has nine excellent programs, one of which is the Kredit Usaha Rakyat (KUR) program. The Kredit Usaha Rakyat program aims to Accelerate the development of the Real Sector and Pemberdayaan Usaha Mikro Kecil, Menengah dan Koperasi
\end{abstract}


(UMKMK), increase access to funding and develop UMKM dan Koperasi for Financial Institutions, as well as help financial mitigation / alleviation and work support, can be used for UKM. The purpose of this research is to study the Public Relations Strategy of the Indonesian Ministry of Koperasi dan Usaha Kecil dan Menengah in disseminating nine of its flagship programs, one of which is the Kredit Usaha Rakyat (KUR) through social media namely facebook, twitter and instagram, containing information needed by UMKMK so that get the latest information from the central government about developments around UMKMK in Indonesia. But of the three existing social media, Facebook is the main focus in socializing the KUR program, because Facebook is a social media that has many features. The theory used is the POAC theory (Planning, Organizing, Actuating, Controlling) by George R. Terry. The paradigm uses constructivism by using descriptive qualitative, while the research method through in-depth interviews and participant observation to obtain primary data. The results of the study found that social media, not only as a place for introduction to information dissemination, but also as a widespread dissemination through information flow

Key word: social media, public relations, socialization, strategy

\section{PENDAHULUAN}

Hubungan Masyarakat (Humas) memiliki strategi yang baik di dalam suatu keberhasilan program atau kegiatan disebuah perusahan swasta atau pun instansi pemerintahan. Humas atau public relations (PR) memiliki andil yang sangat besar dalam berjalannya suatu perusahan atau instansi. Menurut kamus Institut of Public Relations (IPR) terbitan bulan November 1978 yang dikutip dari Edy Sahputra dan Faulina (2011: 13) disebutkan bahwa "Praktik humas atau Public Relations adalah keseluruhan upaya yang dilakukan secara terencana dan berkesinambungan dalam rangka menciptakan dan memelihara niat baik dan saling pengertian antara suatu organisasi dengan segenap khalayaknya". Pemerintah memiliki tujuan dan kepentingan lebih kompleks dari sekedar menjaga citra yang baik pemerintah. Kementerian Koperasi dan UKM, Jakarta memiliki strategi untuk menyosialisasikan sebuah program unggulan yang telah digulirkan oleh Menteri Koperasi dan UKM seperti, memberikan informasi mengenai aggunan saat mengajukan peminjaman, memberikan informasi bagaimana langkah-langkah untuk mengajukan sebuah peminjaman, memberitahu berapa persen bungan yang akan diterima. Seperti yang telah ditetapkan bahwa peminjaman yang ditunjukan kepada Kementerian Koperasi tidak ada anggunan dan juga hanya $9 \%$ bunga yang akan diterima, dan pengajuan peminjaman itu dapat disertai dengan proposal dan juga dapat diajukan kepada beberapa yang telah bekerja sama dengan Kementerian salah satunya bank BNI, bank BRI dan bank Mandiri.

Program Kredit Usaha Rakyat (KUR) ini juga disosialisasikan melalui media sosial. Media sosial adalah saluran atau sarana pergaulan sosial secara online didunia maya (internet). Para pengguna (user) media sosial berkomunikasi, berinteraksi, saling kirim pesan, dan saling berbagi (sharing), dan membangun jaringan (networking). Kementerian Koperasi dan UKM menyosialisasikan program KUR ke media sosial karena media sosial sekarang telah banyak diminati oleh semua kalangan terutama remaja dan dewasa pun menggunakan media sosial juga untuk 
mencari informasi, Kementerian Koperasi dan UKM mempunyai beberapa Account media sosial di Instagram, Twitter serta Facebook. Dan disinilah peran Humas Kementerian Koperasi dan UKM untuk mengelola beberpa account media sosial tersebut agar masyarakat luas memahami tentang program KUR yang telah digulirkan oleh Menteri Koperasi dan UKM yaitu sejak Puspa Prasyoga hingga sekarang diteruskan oleh menteri baru yaitu Teten Masduki.

Upaya dalam meningkatkan kesejahteraan masyarakat Indonesia terutama para pelaku UKM Koperasi, program KUR ini menjadi bagian terpenting dari tugas kesejahteraan masyarakat atau sosial, suatu syarat dari kegiatan kehumasan. Begitupun yang telah dilakukan kehumasan Kementerian Koperasi dan UKM dalam mengembangkan kegitan KUR di media sosial. Dalam penelitian ini ingin mengetahui bagaimana strategi Humas Kementerian Koperasi dan UKM RI dalam menyosialisasikan program KUR melalui media sosial. Kementerian Koperasi dan UKM beberapa menggunakan media sosial sebagai sosialisasi kegiatannya yaitu melalui Facebook, Instagram dan Twitter. Jika dilihat ketiga media sosial yang digunakan memiliki pasar yang berbeda-beda, ini adalah salah satu cara dari mereka agar informasi-informasi yang disampaikan dapat tersebar disemua kalangan usia agar masyarakat dapat terinformasi dengan lengkap. Salah satu informasi yang dimaksud adalah Program KUR.

Kementerian Koperasi dan UKM Republik Indonesia dalam menggunakan media sosial tentunya dilakukan secara prosedural karena menjadi hal yang sangat penting dalam arus informasi yang akan disosialisasikan demi kelancaran yang memiliki sifat informasi internal dan informasi eksternal.

Media sosial adalah bentuk yang tidak jauh berbeda dengan keberadaan dan cara mengerjakan cara kerja komputer. Tiga bentuk bersosial, seperti pengenalan, komunikasi, dan kerjasama bisa dianalogikan dengan cara komputer yang juga membentuk sebuah sistem bagaimana adanya sistem di antara individu atau masyarakat. Bentuk-bentuk itu merupakan lapisan dimana lapisan peta menjadi dasar untuk terbentuknya lapisan lain, pengenalan pada dasarnya merupakan dasar untuk berkomunikasi dan komunikasi merupakan dasar untuk melakukan kerjasama. (Rulli, 2015: 10). Selain itu definisi media sosial menurut Meike dan Young (2013) yang dikutip oleh Rulli, media sosial mengartikan kata media sosial sebagai konvergensi antara komunikasi personal dalam arti saling berbagi antara individu (to be shared one-toone) dan media publik untuk berbagi kepada siapa saja tanpa ada kekhususan individu. (Rulli, 2015: 11). Menurut Van Dijk (2013) dijelaskan oleh Rulli, media sosial adalah platform media yang memfokuskan pada eksistensi pengguna yang memfasilitasi mereka dalam beraktivitas maupun berkolaborasi. Karena itu, media sosial dapat dilihat sebagai medium (fasilitator) online menguatkan hubungan antarpengguna sekaligus sebagai sebuah ikatan sosial. (Rulli, 2015: 11).

Hubungan Masyarakat (Humas) dalam istilah asing sering disebut Public 
Relations. The Public Relations of America bahwa Humas adalah usaha organisasi untuk memperoleh kerjasama dari sekelompok orang. Humas membantu organisasi untuk berinteraksi baik secara efektif dan berkomunikasi dengan publik utama. (Henny Kustini, 2017). Selain itu pengertian Humas adalah manajemen khas yang mendukung pembinaan dan mendukung pembinaan dan pembangunan upaya saling menguntungkan melalui komunikasi, pengertian, penerimaan, dan kerjasama yang baik antara organisasi dengan publiknya. (Ruslan, 2007: 7-8). Humas dapat diartikan sebagai sesuatu sistem secara menyeluruh yang merupakan bentuk komunikasi yang direncanakan yang baik ke internal maupun eksternal dengan bertujuan untuk mendapatkan dukungan dari publiknya dan citra yang positif.

Kementerian Koperasi dan UKM Republik Indonesia, memiliki struktur Humas dimana perannya cukup penting yaitu sebagai jembatan informasi di internal maupun eksternal di Kementerian Koperasi dan UKM Republik Indonesia. Dalam penjelasan tersebut, Humas menjalankan fungsinya bukan sebagai divisi. Selain itu Humas memiliki posisi pada top-level manajemen dalam sebuah struktur organisasi, karena fungsi dan peran utama Humas adalah sebagai tonggak sebuah organisasi.

Strategi Humas dalam Kementerian Koperasi dan UKM Republik Indonesia memiliki tujuan untuk publiknya baik di internal maupun eksternal. Dalam pengembangan strategi, Humas harus merumuskan terlebih dulu, hal-hal yang akan dilakukan. Di dalam strategi, Humas harus mampu membuat pengembangan tujuan, mampu membaca peluang dan bentuk ancaman dari eksternal, membentuk kekuatan dan kelemahan untuk kepentingan internal dan menetapkan sebuah objektivitas agar dapat menghasilkan sebuah strategi alternatif dan memilih strategi untuk dilaksanakan.

Peace dan Robinson mengembangkan langkah-langkah strategi Public Relations sebagai berikut: (1) Menentukan misi perusahaan. Termasuk pernyataan yang umum mengenai maksud pendirian, filosofi dan sasaran perusahaan. (2) Mengembangkan profile perusahaan (Company Profile) yang mencerminkan kondisi internal perusahaan dan kemampuan perusahaan yang dimilikinya. (3) Penilaian terhadap lingkungan eksternal perusahaan, baik dari segi semangat kompetitif maupun secara umum. (4) Analisis terhadap peluang yang tersedia pada lingkungan. Identifikasi atas pilihan yang dikehendaki yang tidak dapat dilengkapi untuk memenuhi tuntutan misi perusahaan. (6) Pemilihan strategi atas objektif jangka panjang dan garis besar strategi yang dibutuhkan untuk mencapai objektif tertentu. (7) Objektif tahunan dan rencana jangka pendek yang selaras dengan objektif jangka panjang dan garis besar objektif. (8) Implementasi atas hal-hal di atas dengan menggunakan sumber yang tercantum pada anggaran dan mengawinkan rencana tersebut dengan sumber daya manusia, struktur teknologi dan sistem balas jasa yang memungkinkan. (9) Review dan evaluasi atas hal-hal yang telah dicapai dalam setiap 
jangka pendek sebagi masukan bagi pengambilan keputusan dimasa yang akan dating. (Ruslan, 2002: 120)

Program adalah rangkaian kegiatankegiatan atau seperangkat tindakan untuk mencapai tujuan. Suatu program dalam mencapai tujuan akan tersusun dengan melakukan perencanaan program. Kementerian Koperasi dan UKM telah mengeluarkan banyak program yang salah satu diantaranya adalah Kredit Usaha Rakyat (KUR). KUR merupakan program yang termasuk dalam kelompok program penanggulangan kemiskinan berbasis pemberdayaan usaha ekonomi mikro dan kecil (klaster 3). Klaster ini bertujuan untuk meningkatkan akses permodalan dan sumber daya lainnya bagi usaha mikro dan kecil. Dan dengan diadakannya program KUR ini dapat membantu masyarakat dalam mengelola usahanya menjadi lebih maju dan berkembang kembali, karena program KUR yang telah digulirkan oleh Kementerian Koperasi dan UKM adalah untuk membantu masyakat serta mensejahterakan masyarakat dengan bunga yang sedikit yaitu 9\%. Serta tujuan utama dibuat program KUR ini adalah:

- Mempercepat pengembangan Sektor Riil dan Pemberdayaan Usaha Mikro, Kecil, Menengah, dan Koperasi (UMKMK).

- Meningkatkan akses pembiayaan dan mengembangkan UMKM \& Koperasi kepada Lembaga Keuangan.

- Sebagai

upaya

penanggulangan/pengentasan

kemiskinan dan perluasan kesempatan kerja.
Sasaran program KUR ini adalah kelompok masyarakat yang telah dilatih dan ditingkatkan keberdayaan serta kemandiriannya pada kluster program sebelumnya. Harapannya agar kelompok masyarakat tersebut mampu untuk memanfaatkan skema pendanaan yang berasal dari lembaga keuangan formal seperti Bank, Koperasi, BPR dan sebagainya. Dilihat dari sisi kelembagaan, maka sasaran KUR adalah UMKMK (Usaha Mikro, Kecil, Menengah dan Koperasi). Sektor usaha yang diperbolehkan untuk memperoleh KUR adalah semua sektor usaha produktif.

Seperti yang dijelaskan George R.

Terry dalam Sukarna (2011: 10) menjelaskan teori Manajemen $P O A C$, sebagai berikut: (1) Planning (perencanaan), didefinisikan sebagai penentuan terlebih dahulu yang harus dikerjakannya. Dalam perencanaan terlibat unsur penetuan yang berarti bahwa dalam perencanaan tersebut tersirat pengambilan keputusan. Karena itu perencanaan dapat dapat dilihat sebagai suatu proses dalam suatu kerangka untuk mengambil keputusan dan penyusunan rangkaian tindakan selanjutnya di masa depan. Rencana yang baik akan merumuskan tujuan dan sasaran apa yang ingin dicapai. Perencanaan adalah kumpulan keputusan-keputusan. Planning adalah suatu proses untuk menetukan rencana (plan). (2) Organizing (organisasi), tujuan pengorganisasian adalah untuk mengelompokkan kegiatan sumber daya manusia dan sumber daya lainnya yang dimiliki agar pelaksanaan dari suatu rencana dapat dicapai secara efektif dan ekonomis. 
Menurut Handoko, pengorganisasian ialah pengaturan kerja bersama sumber daya keuangan, fisik dan manusia dalam organisasi. Pengorganisasian merupakan penyusunan stuktur organisasi yang sesuai dengan tujuan organisasi, sumber daya yang dimilikinya, dan lingkungannya yang melingkupinya.

Actuating (pelaksanaan/penggerakan), masalah penggerakan berkaitan erat dengan manusia dan paling sulit dilakukan dari semua fungsi manajemen. Menggerakkan manusia merupakan hal yang paling sulit, karena manusia pekerja adalah makhluk hidup yang mempunyai harga diri. Perasaan dan tujuan yang berbeda-beda. Fungsi penggerakan ini diibaratkan sebagai kunci mobil, mobil hanya akan dapat bergerak jika kunci stater telah berfungsi. George R. Terry memberikan definisi actuating (penggerakan) adalah membuat semua anggota kelompok agar mau bekerja sama dan bekerja secara ikhlas serta bergairah untuk mencapai sesuai dengan perencanaan dan usaha-usaha pengorganisasian. (4) Controlling (pengawasan), proses pemantauan, penilaian, dan pelaporan rencana atas pencapaian tujuan yang telah ditetapkan untuk tindakan korektif guna penyempurnaan lebih lanjut.pengawasan bukan hanya untuk mencari kesalahankesalahan, tetapi berusaha untuk menghindari terjadinya kesalahan-kesalahan serta memperbaikinya jika terdapat kesalahan kesalahan. Jadi, pengawasan dilakukan sebelum proses, saat proses, dan setelah proses, yakni hingga hasil akhir diketahui.
Teori Manajemen $P O A C$ ini sesuai dengan penelitian ini karena teori ini menjelaskan bahwa bagaimana Humas mampu mempersiapkan konsep dan langkah-langkah strategi Humas dalam struktur organisasi Kementerian Koperasi dan UKM Republik Indonesia yang diimplementasikan untuk internal maupun eksternal. Penulis mengkaitkan teori ini dengan Strategi Humas dalam menyosialisasikan program KUR melalui media sosial, dimana dalam penggunaan media sosial, Kementerian Koperasi dan UKM Republik Indonesia menjelaskan disetiap informasi yang diperoleh, selanjutnya diproses melalui beberapa tahapan seperti review kembali jika sudah tidak ada kesalahan lagi maka informasi tersebut dapat diinformasikan kembali melalui media sosial yang berbeda-berbeda. Dengan strategi Humas menggunakan media sosial yang berbeda-beda, maka diharapkan respon atau feedback yang akan diperoleh dari sosialisasi informasi juga akan berbeda. Maka terlihat dengan jelas, bahwa Kementerian Koperasi dn UKM Republik Indonesia, khususnya Humas harus dapat memilah dan memilih media sosial yang tepat untuk digunakan dalam proses penyebaran informasi.

\section{METODE PENELITIAN}

Metode yang digunakan dalam penelitian ini adalah studi kasus. Studi kasus adalah strategi penelitian dimana di dalamnya peneliti menyelediki secara cermat suatu program, peristiwa, katifitas, proses atau sekelompok individu. Kasuskasus dibatasi oleh waktu dan aktifitas dan 
peneliti mengumpulkan informasi secara lengkap dengan menggunakan berbagai prosedur pengumpulan data berdasarkan waktu yang telah ditentukan. (Creswell, 2008: 19).

Dikatakan sebagai studi kasus, karena peneliti melihat adalanya permasalahan yang terjadi di dalam Divisi Hubungan Masyarakat Kementerian Koperasi dan UKM Republik Indonesia dalam menyosialisasikan informasi dari internal kepada publik melalui jejaring media sosial. Objek penelitian adalah Strategi sosialisasi program melalui media sosial. Data primer diperoleh melalui wawancara yang dilakukan oleh beberapa narasumber. Data sekunder diperoleh melalui studi kepustakaan. Dari hasil wawancara peneliti dengan Kepala Bagian Hubungan Masyarakat Bapak Sudarmono dan Staf Hubungan Masyarakat Kementerian Koperasi dan UKM Republik Indonesia Bapak Ali Muhammad. Lebih jelasnya dalam metode penelitian ini digunakan karena adanya hubungan yang dapat dihubungkan antara metode penelitian dengan kerangka pemikiran. Hal ini tentunya sejalan dengan penggunaan kerangka pemikiran karena dalam penelitian yang dimaksud adalah untuk memberikan informasi sosialisasi program KUR (Kredit Usaha Rakyat/KUR) dan solusi atas pemecahan masalah yang dihadapi oleh Hubungan Masyarakat Kementerian Koperasi dan UKM Republik Indonesia.

\section{HASIL DAN PEMBAHASAN}

Kementerian Negara Koperasi dan UKM RI adalah kementerian dalam
Pemerintah Indonesia yang bertugas membantu Presiden dalam merumuskan kebijakan dan koordinasi dibidang perumusan kebijakan, koordinasi pelaksanaan, pengelolaan kekayaan, pengawasan, dan penyampaian laporan evaluasi dibidang tersebut. Selain itu Visi dan Misi yang diemban oleh Kementerian Koperasi dan UKM Republik Indonesia adalah mendukung segala hal yang berhubungan Koperasi dan Usaha Kecil Menengah (KUMK) dengan tujuan meningkatkan pertumbuhan ekonomi yang berkelanjutan.

\section{Strategi Menyosialisasikan Informasi KUR}

Humas Kementerian Koperasi dan UKM Republik Indonesia dalam menyosialisasikan program KUR melalui media sosial facebook agar banyak masyarakat tahu mengenai program KUR itu sendiri, serta dapat juga melihat dengan jelas prosedur mengajukan peminjaman melalui Kementerian Koperasi dan UKM Republik Indonesia atau beberapa bank swasta yang bergabung dengan Kementerian Koperasi untuk pengajuan peminjaman dana program KUR.

Kepala Bagian Humas Kementerian Koperasi dan UKM Bapak Sudarmono menjelaskan strategi Humas Kementerian Koperasi dan UKM Republik Indonesia dalam Perencanaan dan Pengorganisasian pada pelaksanaan Program KUR oleh Humas Kementerian Koperasi ini telah dibuat sejak 2007 bahwa program ini sudah ada sejak pemerintahan Susilo Bambang Yudhoyono saat menjabat sebagai presiden RI keenam, dan program ini dibuat untuk 
memudahkan masyarakat dan para UKM Koperasi dalam mengakses modal pembiayaan. Intinya program KUR ini para UKM Koperasi untuk mempermudah akses pembiayaan kepada Koperasi UKM serta sektor rill lainnya, karena Kementerian Koperasi telah memikirkan dengan baik bahwa masyarakat sulit untuk mendapatkan pinjaman kepada perbankan yaitu dengan bunga yang sangat tinggi dan juga sulitnya untuk proses peminjaman. Sehingga membuat Kementerian Koperasi dan UKM menggulirkan program ini karena bunga yang ditawarkan oleh Kementerian Koperasi dan UKM yaitu hanya 9\%, dan dengan bunga yang kecil akan mempermudah masyarakat atau sektor rill lainnya untuk mengajukan proposal peminjaman kepada Kemeneterian Koperasi dan UKM.

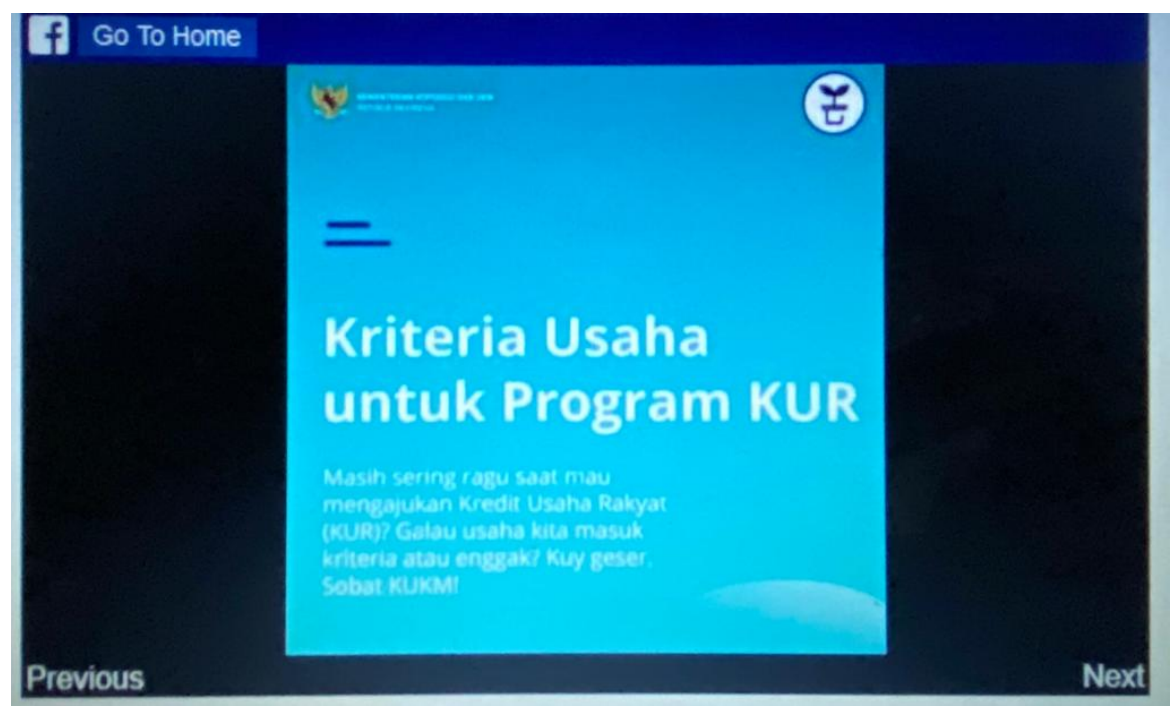

Gambar 1. Sosialisasi Prosedur Proses Pengajuan Peminjaman KUR

Faktor yang mendasari Kementerian Koperasi dan UKM Republik Indonesia membuat Program KUR, agar mempermudah masyarakat, sektor rill, dan UKM Koperasi mendapat pinjaman dengan mudah serta dengan bunga yang cukup rendah yaitu 9\% dan sekarang program KUR ini dengan mudah diberikan yaitu senilai 25 Juta Rupiah tanpa aggunan, tetapi dengan syarat usaha yang didirikannya sudah berdiri selama enam bulan dan sebagai bentuk dijaminkannya, adalah usaha itu sendiri. Bank swasta yang bekerjasama dengan Kementerian Koperasi dan UKM untuk menyalurkan program ini adalah bank BRI, bank BNI serta bank Mandiri. Lalu persyaratan yang mudah inilah membuat para bank swasta mau bergabung yaitu bila para UKM atau masyarakat rill meminjam senilai 25 juta tidak diberikan aggunan, tetapi bila ingin meminjam diatas 25 Juta akan diberikan aggunan sesuai dengan persyaratan masing-masing bank tersebut yang telah disepakati oleh pihak bank dan Kementerian Koperasi dan UKM. 


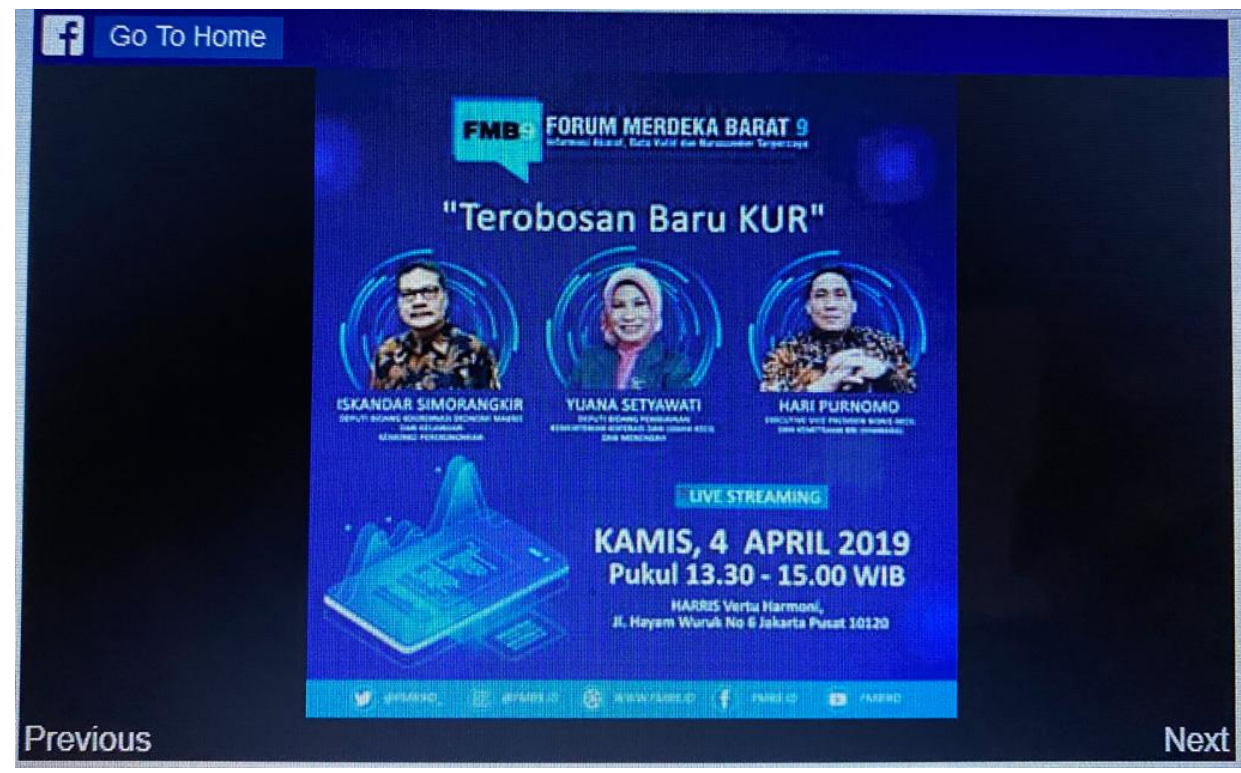

Gambar 2. Sosialisasi Terobosan Baru KUR Live di Facebook

Strategi Humas Kementerian Koperasi dan UKM Republik Indoensia untuk menyosialisasikan program KUR melalui media sosial berusaha menyajikan informasi mengenai program terobosan baru KUR yang dilakukan dengan format live di Facebook, menghadirkan para pembicara sesuai pakar bidangnya. Hal ini dilakukan komunikasi interaktif secara langsung antara narasumber dengan masyarakat. Disini diharapkan dapat terjadi komunikasi Tanya Jawab secara efektif guna mempertanyakan terobosan baru KUR. Sehingga masyarakat langsung dapat mengetahui perkembangan hal baru yang ada di program KUR tersebut.

\section{Strategi Dalam Menghadapi Informasi Penundaan Program KUR}

Media sosial memiliki peran yang sangat penting, terutama untuk berinteraksi dengan masyarakat, serta menyosialisasikan program-program yang digulirkan oleh Kementerian Koperasi dan UKM Republik Indonesia atau pun kegiatan yang sedang dilakukan Menteri Koperasi, bahkan program yang sudah di informasikan, kemudian muncul informasi adanya penundaan pada program KUR yang lebih dipermudah. agar masyarakat menjadi lebih tahu mengenai Kementerian Koperasi itu sendiri terutama terhadap Program-program Kementerian Koperasi dan UKM. Namun dalam konteks penundaan peminjaman KUR lebih dipermudah sifatnya sangat bias, dikarenakan kejelasan cara-cara tersebut tidak sesuai dengan praktek dilapangan. Oleh karena itu masyarakat menjadi bingung. Kebingunan inilah dapat memicu kesalahpaman di masyarakat. 


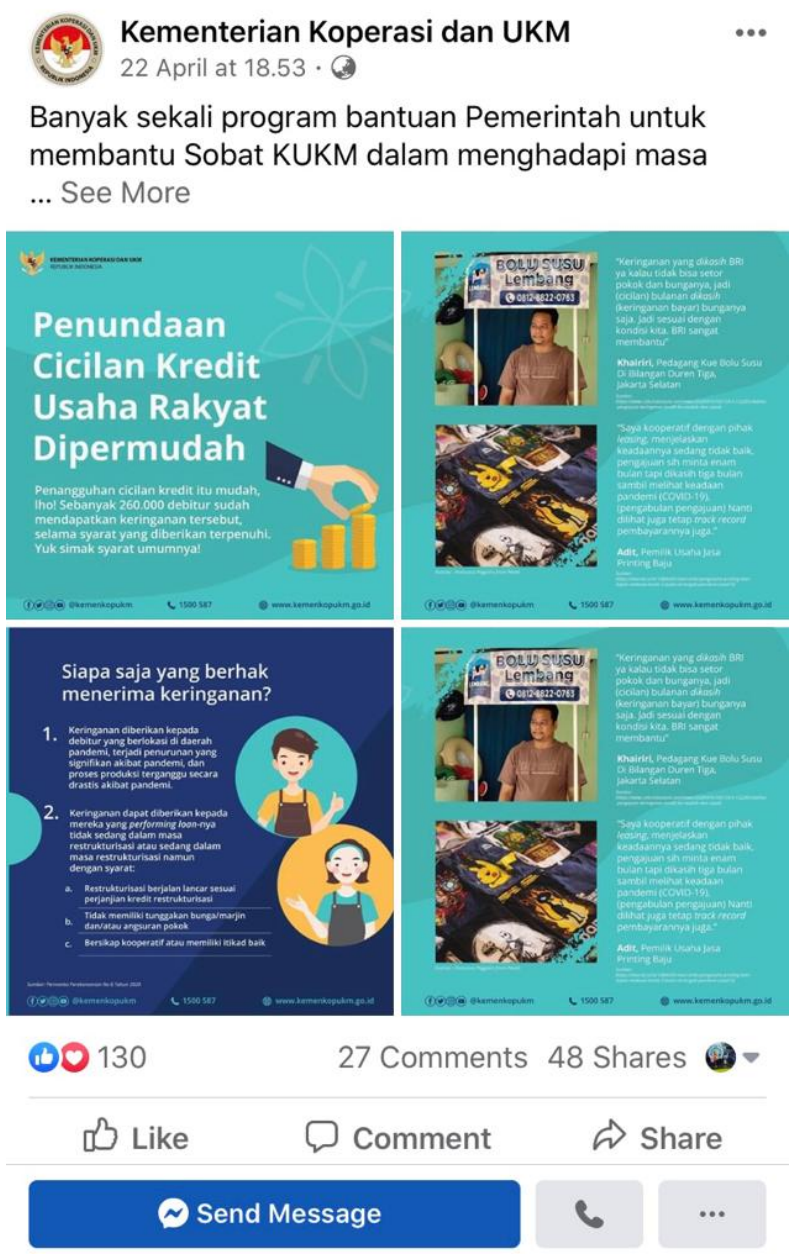

Gambar 3. Sosialisasi Informasi Penundaan Cicilan KUR Dipermudah

Humas Kementerian Koperasi dan UKM Republik Indonesia untuk menyosialisasikan program KUR seorang peran Humas menyosialisasikan program KUR adalah sangat penting karena dapat mempermudah segala aktifitas dan kinerja Humas Kementerian Koperasi dan UKM Republik Indonesia pada saat memantau, baik pertanyaan-pertanyaan yang ditanyakan seputar program KUR kepada admin, serta komentar-komentar yang diberikan untuk Kementerian Koperasi dan UKM, salah satu contoh adalah ada masyarakat yang memberitahukan kepada admin media sosial kami mengenai aggunan yang diberikan kepada peminjam, yang seharusnya aggunan untuk peminjaman dibawah 25 Juta Rupiah tidak ada, dan itu yang membuat Humas Kementerian Koperasi menyelidiki tentang kabar yang diberikan masyarakat melalui account media sosial Kementerian Koperasi. Selanjutnya Kementerian Koperasi pun akan menindaklanjuti bank-bank swasta tersebut yang memberikan aggunan tersebut. Media sosial memiliki peran yang sangat penting, terutama untuk berinteraksi dengan masyarakat, serta menyosialisasikan program-program yang digulirkan oleh 
Kementerian Koperasi dan UKM atau pun kegiatan yang sedang dilakukan Menteri Koperasi, agar masyarakat menjadi lebih tahu mengenai Kementerian Koperasi itu sendiri terutama terhadap Program-program Kementerian Koperasi dan UKM.

\section{Strategi Dalam Manangani Feedback Informasi "Positif atau Negatif"}

Seorang Humas melakukan pengawasan pada setiap orang yang masuk Pertanyaan pertanyaan apa saja yang selalu ditanyakan oleh pengikut di account media sosial Kementerian Koperasi dan UKM. Pertanyaan yang biasanya ditanyakan yaitu mengenai cara mengakses KUR, lalu mengapa didaerah satu dan daerah dua atau daerah lainnya masih ada aggunan terlebih Kementerian Koperasi dan UKM sendiri telah mengatakan bahwa tidak ada aggunan untuk peminjaman 25 juta kebawah.
1. Dampak positif dan negative dengan adanya program KUR

- Dampak Positif

a. Masyarakat dapat dengan mudah untuk mengajukan peminjaman

b. Banyak para UKM yang sukses dan berkembang

- Dampak Negative

a. Banyak permainan perbankan dengan mengatas namakan KUR

b. Para UKM yang sering menunggak dalam membayar Kreditnya

2. Strategi Humas Kementrian Koperasi dan Usaha Kecil Menengah untuk menyosialisasikan program KUR melalui media sosial 


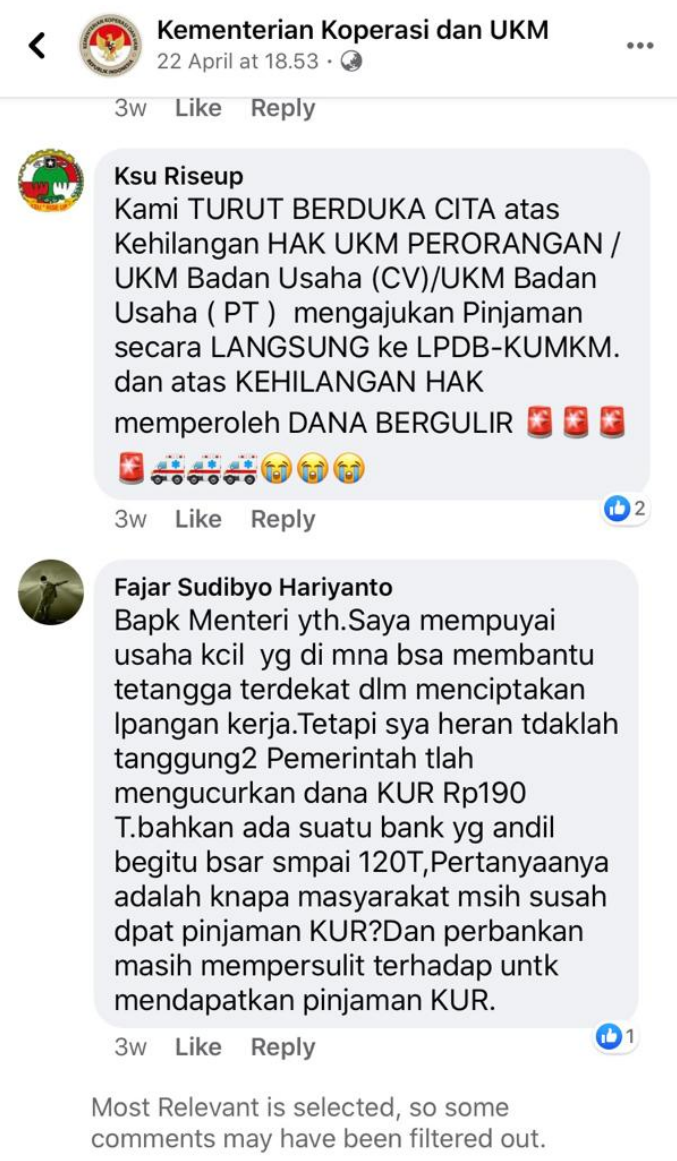

Gambar 4. Komentar Masyarakat Atas Penundaan Program Cicilan KUR

Melalui feedback yang diterima dalam penggunaan media sosial merupakan sebuah respon yang positing atau negatif, sehingga dalam rangka menyosialisasikan informasi, Humas Kementerian UKM Republik Indonesia harus memiliki daya tarik sendiri bagi masyarakat. Selain itu berusaha memberikan respon dengan baik atas semua feedback yang diterima dari komentarkomentar masyarakat. Admin dari Humas Kementerian UKM Republik Indonesia juga melakukan pengelolaan jejaring media sosial yang baik. Humas selaku tonggak ujung sebuah lembaga berusaha memberikan feedback dengan baik dan cepat agar masyarakat yang berkomentar merasakan adanya kepuasan atas apa yang menjadi pertanyaan-pertanyaan masyarakat.

Bila ada kesalahpahaman dalam postingan tersebut ini menjadikan rekomendasi Humas, dan Humas pun langsung memberikan arahan mengenai kasus tersebut kepada Deputi yang berwenang. Kemudian Deputi yang berwenang terhadap KUR adalah Deputi pembiayaan, lalu Humas pun memberikan arahan kepada Deputi pembiayaan bahwa ada komentar seperti ini mengenai program KUR yang terjadi diwilayah ini, karena humas tidak berwewenang untuk 
sembarangan berbicara, karena Humas adalah sebagai mediator.

Humas Kementerian dan UKM Republik Indonesia berusaha menyajikan informasi mengenai program KUR ataupun program- program lainnya dengan menggunakan bahasa yang dapat dimengerti oleh masyarakat sekarang, serta memberikan konten konten yang jelas yang dapat dimengeriti juga oleh masyarakat lainnya.

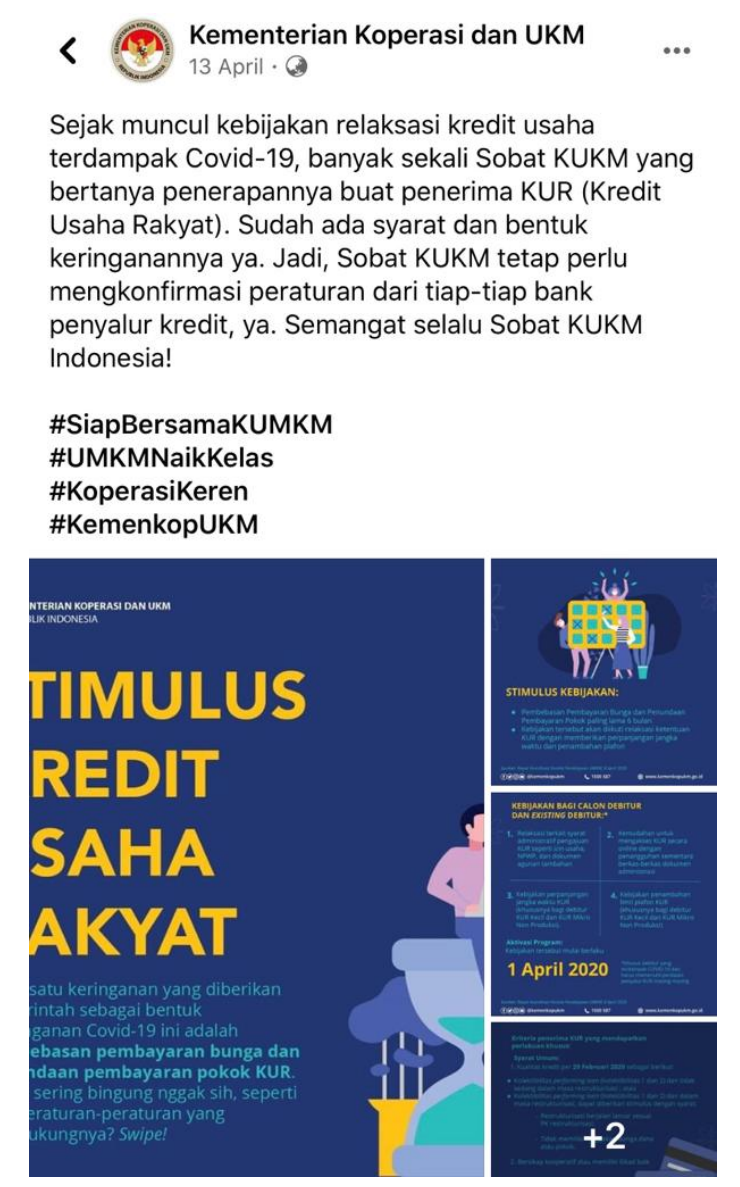

Gambar 5. Sosialisasi Kebijakan Baru KUR

\section{Strategi Sosialisasi Dalam Jumlah Postingan Motivasi dan Penggunaan Bahasa}

Humas Kementerian Koperasi dan UKM Republik Indonesia tidak menghitung seberapa kali dalam sehari postingan KUR diposting, karena dilihat juga terhadap Menteri Koperasi yaitu Teten Masduki yang sedang memberi himbauan mengenai program KUR maka Humas Kementerian Koperasi dan UKM memposting mengenai program KUR, serta dilihat juga melalui kegiatan-kegiatan mengenai konsetuasional itu sendiri juga bila sedang membicarakan KUR atau ada program himbauan baru mengenai KUR maka akan diposting melalu media sosial tersebut. 


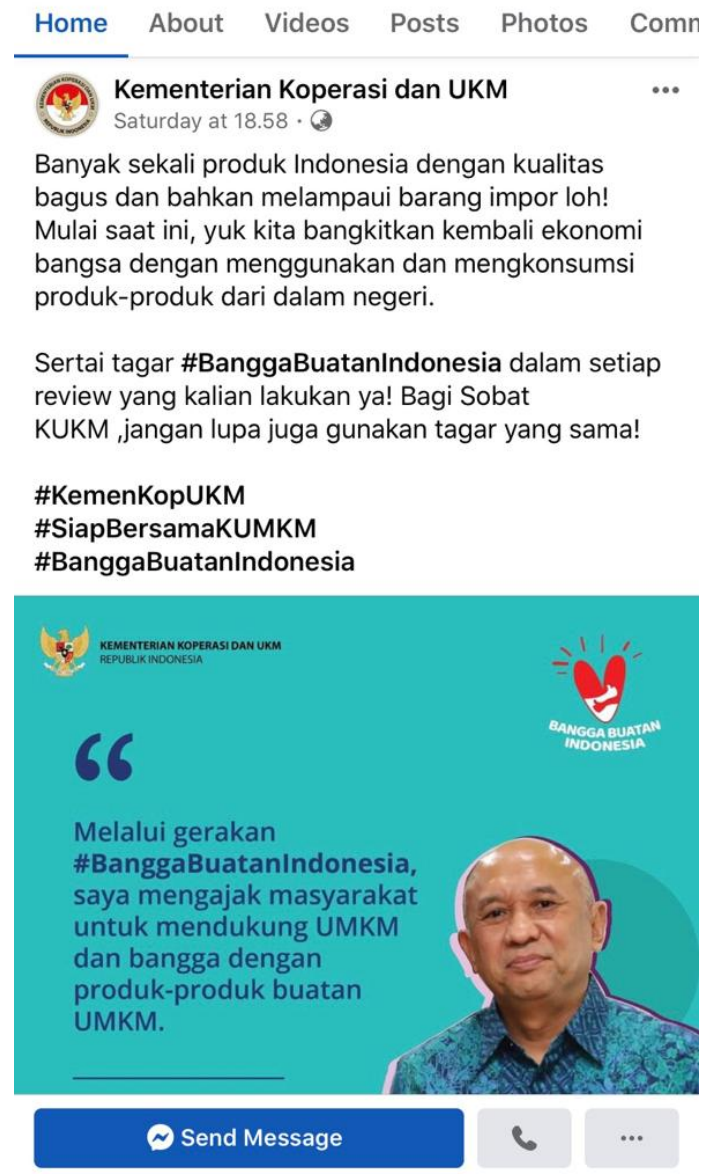

Gambar 6. Sosialisasi Motivasi Cinta Produk Dalam Negeri

Pertanyaan yang selalu ditanyakan oleh pengikut di account media sosial Kementerian Koperasi dan UKM, yaitu mengenai jaminan KUR serta komentarkomentar dari para UKM yang telah mengajukan pinjaman ternyata masih ada yang diberikan anggunan saat peminjaman tersebut. Focus media sosial yang digunakan Kementerian Koperasi dan UKM untuk menyosialisasikan program KUR adalah media sosial Facebook, karena facebook dapat berinteraksi langsung dengan pengikut lainnya dan juga facebook memiliki karakter yang banyak untuk menulis mengenai pemberitahuan atau pun untuk menyosialisasikan program mencintai produk Indonesia yaitu para UMKM. Tetapi
Kementerian Koperasi dan UKM juga tetap mengupload ke media sosial lainnya seperti Instagram dan juga Twitter, tetapi kalau di Instagram hanya mengenai kegiatan yang dilakukan oleh menteri itu sendiri serta diberikan caption sesederhana dan semenarik mungkin dan pengaruh followers atau pengikut pun menjadi salah satu faktor utama juga. Selain itu banyak pertanyaan yang disampaikan melalui facebook, sehingga menjadikan facebook sebagai fokus dari media sosial yang digunakan Kementerian Koperasi dan UKM Republik Indonesia.

Melalui manajemen POAC (Planning, Organizing, Actuating dan Controlling) yang dilakukan dan diterapkan oleh Humas 
Kementerian Koperasi dan UKM RI, maka jalannya sebuah kinerja dalam lembaga akan dapat diukur dengan indikator-indikator yang sesuai dengan data yang ada sebagai penunjang kinerja dalam manajemen tim. Sehingga manajemen yang baik ini akan menjadi tolak ukur sebuah organisasi agar dapat mencapai tujuan bersama. Selain manajemen yang sudah diterapkan dengan baik, diperlukan SDM yang berkualitas dalam bidangnya, agar kinerja yang ada dapat menjalan hingga menyelesaikan tugasnya dengan sesuai target yang ditentukan. Jika masih dirasa kurang maksimal dari beberapa elemen yang ada, dapat ditambahkan dengan fasilitas yang memadai untuk menunjang kelancaran pekerjaan para SDM agar dapat lebih cepat dan segera tuntas menyelesaikan pekerjaannya.

Dukungan manajemen SDM yang baik memang tidak cukup, tetapi wawasan dan pengetahuan yang selalu mengikuti informasi-informasi terkini, hal ini dapat melengkapi sebuah manajemen yang dapat lebih maju dan menjadi contoh. Selain itu manajemen SDM juga harus dibekali dengan kegiatan-kegiatan seperti seminar, workshop, kompetensi atau sertifikasi, hal ini untuk meningkatkan kualitas diri dari masing-masing SDM yang ada, sehingga rasa tanggung jawab, kemandirian, kepemimpinan, kreatifitasnya dan inisiatifnya dapat terasah dengan sempurna. Seorang Humas yang dapat dikatakan baik adalah mampu membaca keadaan atau situasi di internal lembaga mereka bekerja, karena dilingkungan internal inilah yang harus dikuasai terlebih dahulu, misalnya harus dikenali terlebih dulu bagaimana karakter dan sifat-sifat tim yang ada, sehingga ketika ada masalah yang datang dari pihak eksternal maka seorang Humas harus mampu menghadapi hingga dapat menyelesaikannya. Seorang Humas harus peka dengan masalah yang ada, mengikuti perkembangan isu-isu yang sedang terjadi. POAC sudah diterapkan oleh Humas Kementerian Koperasi dan UKM, mengingat tugas dan kewajiban seorang Humas disini harus mampu bekerja secara multitalenta, mereka dituntut untuk dapat berkerja dengan cepat, tepat dan inisitaif. Seperti hasil dari penelitian ini bahwa seorang Humas harus mampu memberikan informasi tepat dan cepat bagi seluruh UKM di Indonesia. Beban tugas yang kerjakan cukup besar dan bertanggungjawab pada informasi seputar KUR tanpa harus ada kesalahan dalam menyampaikannya. Mampu mengatasi permasalahan secara cepat dengan merespon komentar yang masuk dari berbagai macam pertanyaanpertanyaan yang masuk seputar UKM.

\section{SIMPULAN}

Strategi Humas dalam menyosialisasikan sebuah program terutama salah satu program unggulan yaitu program KUR harus dapat memberikan dampak postif kepada masyarakat, karena masyarakatlah yang akan menilai bagaimana baik buruknya program ini terealisasikan. Kementerian Koperasi dan UKM Republik Indonesia yang dibantu oleh Humas dalam menjalankan sebuah program KUR dan juga menyosialisasikan program tersebut melalui media sosial seperti Facebook, Instagram 
dan juga Twitter. Humas Kementerian Koperasi dan UKM dapat menyosialisasikan program KUR tersebut dengan baik dan juga menjawab pertanyaan-pertanyaan yang diberikan kepada para pengikut di media sosial dengan cepat merupakan hal yang baik dan patut diapresiasi.

Program KUR itu sendiri juga mendapat sambutan baik dari para pelaku UKM Koperasi dan juga masyarakat Indonesia, karena program KUR ini membantu masyarakat mendapat pinjaman dengan bunga yang rendah yaitu $9 \%$ dan juga tanpa aggunan bila peminjaman yang diminta dibawah 25 juta rupiah. Kementerian Koperasi dan UKM membuat program KUR ini memiliki alasan yang sangat mendasar, yaitu untuk mempercepat pengembangan Sektor Riil dan Pemberdayaan Usaha Mikro, Kecil, Menengah, dan Koperasi (UMKMK), meningkatkan akses pembiayaan dan mengembangkan UMKM \& Koperasi kepada Lembaga Keuangan, sebagai upaya penanggulangan/pengentasan kemiskinan dan perluasan kesempatan kerja. Dalam komunikasi yang responsif yang dilakukan Kementerian Koperasi dan UKM Republik Indonesia dalam memberikan klarifikasi dan penjelasan dari komentar-komentar yang negatif atau positif harus tetap professional, menggunakan bahasa dalam komunikasi yang mudah dimengerti dan dipahami oleh semua orang, sehingga menghindari terjadinya kesalahpemahaman terhadap klarifikasi yang diberikan.

\section{UCAPAN TERIMA KASIH}

Peneliti mengucapkan terima kasih sebesar-besarnya kepada Kementerian Koperasi dan UKM RI yang telah memberikan kesempatan untuk melakukan penelitian, khususnya kepada Bapak Sudarmono (Kepala Bagian Humas Kementerian Koperasi dan UKM RI), Bapak Ali Muhammad (Staf Humas Kementerian Koperasi dan UKM RI). Yayasan Budi Luhur Cakti Bapak Kasih Hanggoro, MBA, Rektor Universitas Budi Luhur Bapak Dr. Ir. Wendi Usino, MS.c., MM., Dekan Fakultas Ilmu Komunikasi Universitas Budi Luhur Ibu Dr. Nawiroh Vera, M.Si, Jagadtani.id, Departemen Sains Komunikasi, Fakultas Ekologi dan Manusia IPB University.

\section{DAFTAR PUSTAKA}

Alwasilah, A. Chaedar. (2011). Pokoknya Kualitatif (Dasar-Dasar Merancang dan Melakukan Penelitian Kualitatif). Jakarta: PT. Dunia Pustaka Jaya

Budiono M.A. (2005). Kamus Ilmu Populer Internasional. Surabaya. Alumni

Bungin, Burhan. (2006). Metode Penelitian Kualitatif. Jakarta: Kencana Prenada Media Group

Cangara, Hafied. (2015). Pengantar Ilmu Komunikasi. Jakarta: PT Rajagrafindo Persada

Dhoiri, Taufik Rochman, dkk. (2007). Sosiologi Suatu Kajian Kehidupan Masyarakat. Jakarta: Yudhistira

Handoko, T. Hani. Manajemen, Edisi 2. Yogyakarta: BPFE

Husein, Martani, Lubis, Hari S.B. (1987). Teori Organisasi (Suatu Pendekatan Makro), Pusat Antar Ilmu-Ilmu Sosial. Jakarta: Universitas Indonesia 
Ihrom. (2004). Bunga Rampai Sosiologi Keluarga. Jakarta: Yayasan Obor Indonesia

Kustiny, Henry. (2017). Communication Skill. Sleman: CV. Budi Utama

Kasali, Rhenald. (2002). Manajemen Humas dan Komunikasi. Jakarta: RajaGrafindo Persada.

Kriyantono, Rachmat. (2010). Teknik Praktis Riset Komunikasi. Jakarta: Fajar Interpratama

Mulyana, Deddy.(2001). Metode Penelitian Kualitatif. Bandung: Remaja Rosdakarya.

Ruslan, Rosady. (2007). Manajemen Public Relations Dan Media Komunikasi, edisi revisi. Jakarta: PT. Raja Grafindo

Sugiyono. (2011). Metode Penelitian Kuantitatif, Kualitatif. Bandung: Alfabeta

Sukarna. (2011). Dasar-Dasar Manajemen. Jakarta: CV. Mandar Maju

Sumber Internet

http://www.tnp2k.go.id/

http://kur.ekon.go.id/

https://digilib.esaunggul.ac.id

http://repository.usu.ac.id

https://kbbi.web.id/sosialisasi 